\title{
Religion and atheism from a gender perspective ${ }^{\star}$
}

IN August 2010 the Finnish Broadcasting Company YLE, summarising the results of the World Values 2005 survey, released them under the headline 'Religion is a women's issue. Is atheism and secularity then, by contrast, an issue for men? It is tempting to answer the question positively when one looks at the names of the new atheist bestselling authors, or the names in the index lists in the back pages of books with reference to atheism, as well as the names of the researchers into atheism and secularity: they tend to be male much more often than female. In this paper I will examine the ways in which both religiosity and non-religiosity and atheism are gendered phenomena. I also look at feminists' views on religion by pointing out in which ways they intersect with the opinions of the new atheist texts. ${ }^{1}$ Because both (second $w^{2} e^{2}$ ) feminists and atheists consider religion from a relatively narrow point of view, I'll bring out the ways in which the contemporary study of religion defines, sees and studies religion and religiousness, while it takes the concept of gender seriously.

* An earlier version of this artice was published in Finnish: Tiina Mahlamäki 2011. 'Uskonto, uusateismi ja sukupuoli' [Religion, new atheism and gender]. In: Jussi K. Niemelä (ed.), Mitä uusateismi tarkoittaa? [What New Atheism Means]. 150-74. Turku: Savukeidas.

1 With the term 'new atheist' I refer to well-known and distinguished writers such as Richard Dawkins, Sam Harris, Daniel Dennett and Christopher Hitchens. I'm aware that they do not think or write identically, but they join in a common and quite similar understanding of the concepts of religion, religious belief and religiousness.

2 By this I mean the Women's Liberation Movement and feminist research up until 1980s. The focus (concerning religion) was on revealing the patriarchal structures of the world religions and the multiple ways in which religions have subordinated women.
I also discuss the seemingly indisputable fact which the statistics point to; namely that women tend to be more religious than men and men tend to be more often atheist than women (my examples are mostly from the Finnish context). I also present some models of explanation which scholars have applied to these problems.

First of all, I'll clarify my own standpoint regarding the issue. I'm interested in the ways in which the atheist critique has become a visible part of the public discussion of religion. As an ideological statement and a form of irreligiousness, atheist discourse provides interesting data for the study of religions. Although atheism and secularity are not institutionalised forms of religion, they can be seen as ideologies because they are not merely describing the world; they also want to change it (Davie \& Woodhead 2009: 525). For my part, I do not position myself as an atheist, nor as a member of any religious community.

In Finland, at least, some scholars of religion are taking atheism as a standpoint for studying and teaching comparative religion. The critique of religion, as being the mission of the new atheist discourse, is imparted by them as a foundational trait within comparative religion: the less religion, according to this view, the better off the world is. They hold that the task of comparative religion is to prove the arguments of religious traditions to be unreliable, false and untrue. According to this line of reasoning, religions are regarded as harmful both for individuals and societies (see, for example, Visala 2010: 31).

I don't perceive this to be the task of comparative religion, but rather agree with Teemu Taira's (2003: 60-1) proposal that scholars of comparative religion should examine religions in their social contexts (religion as it is lived and experienced, at a certain time and place). The critical study of religion should mean that we take seriously the concepts of power, class, 
race, ethnicity, and gender, which in many ways are connected to the practices of religion. This raises important questions: who speaks for whom, whose voices are privileged and whose are silenced? (Beattie 2007: 7.)

I'll start with a short tour of the relationship between religion and science, as it seems to constitute an integral part, both of the new atheistic discourse and the gender problematic.

\section{The war between science and religion - a strong and durable metaphor}

The conflict between religion and science can be seen as an underlying basic principle in the texts of the new atheists, in which the purpose is very often to demonstrate how religious beliefs are false and incorrect. Religion and science are seen as separate and opposing arenas. Religious beliefs and scientific knowledge are perceived to be mutually exclusive, and their contemporaneous existence is at variance both in society and in the minds of individuals. This attitude has its roots in the Age of Enlightenment, but it became visible and clear cut in the latter part of the nineteenth century, when science, as we have come to know it, developed. During that period science emerged as an independent domain within society, and to work as a scientist became a real profession. The modern scientist had to build his identity by clearly separating himself from the area of religion. Formerly, however, science and religion had not occured in separate domains, but were integrated in the sphere of natural philosophy. Western science or natural philosophy was born within Christianity (see e.g. Brooke 1991). As Gavin Hyman (2010: 103) puts it, 'it seemed entirely natural that a scientist should also be a priest' and it seemed even more natural that both scientists and priests were men. The identity building project of the scientist was definitely a male project, as it was not possible for women - with some exceptions to enter into academic education or to concentrate on doing research until the late nineteenth century (see Beattie 2007) - at least in Finland, women who wanted to begin university studies had to request a special dispensation on the grounds of their gender.

At the same time, at the end of the nineteenth century, the metaphor of a conflict or war between science and religion rapidly evolved. Religion (the church) was perceived as the active and aggressive party in the conflict, and was accused of having prevented the development of science in previous cen- turies. Within the metaphor of conflict ${ }^{3}$ historical events tend to be perceived one-sidedly and simplistically; the history of science and religion shows that the roots of conflicts (or events identified as conflicts) are multidimensional disagreements on, for instance, power, authority and resources (see e.g. Brooke 1991, Ferngren 2002). Similarly, the concrete conflict between science and religion at the end of nineteenth century was not born, according to Tina Beattie, from a struggle between religious and scientific ways of explanation' but merely from a struggle of power and authority between men of science and men of God. 'The triumph of science over theology required the total discrediting of theological knowledge.' (Beattie 2007: 20.) This active discrediting is still being continued by the new atheists.

When the metaphor of the conflict between science and religion is used, it does not concern all scientific knowledge and research but, more specifically, the natural sciences (in Finnish there is no linguistic separation between the natural sciences and other disciplines: one word, tiede, fits all disciplines from the arts and humanities to social sciences and the natural sciences). It is not unproblematic to transfer the contemporary notion of science to history there was, for instance, no distinction between the Creator and His creation within natural philosophy; the scholars of natural philosophy studied both. (See e.g. Brooke 1991: 6-7; Ferngren 2002: xi-xiv.) Neither was the other side of the conflict, religion, not just any religion, but historically the church, and for the most part the Catholic Church. The new atheists use the word 'religion' mostly to refer to the established church of their own country, or more often, to conservative and fundamentalist forms of Christianity and Islam. In its modern form the metaphor of conflict has a slightly different configuration; within the new atheist discourse (natural) science is seen to overpower all religious traditions and beliefs, because it offers neutral and justifiable knowledge, while religions, even liberal and moderate ones, are seen as a platform to more fundamentalist views (see, for example, Pyysiäinen 2011). The metaphor of war has thus returned and serves the new atheists on their historical crusade against religions, ultimately in order to exterminate them.

3 The origin of this influential and enduring metaphor lies mainly in two books: John William Draper's History of the Conflict between Religion and Science (1874) and Andrew Dickson White's A History of the Warfare of Science with Theology in Christendom (1896). See also Brooke 1991 and Ferngren 2002. 
At the core of the conflicts of the late nineteenth century, as well as at the core of the new atheism today is Charles Darwin's theory of natural selection. The model is conveniently transferred from biology to other disciplines in order to explain, for instance, the evolution of societies - but it has also been used as a justification for eugenics and racism (see Brooke 1991: 275-320). In the new atheist discourse, especially in the works of Richard Dawkins, evolution theory works as a weapon against religions. Here the counterpart appears to be fundamentalist Christianity only, with its firm belief in creationism - which is to say, reading the Genesis as a historical and biological textbook. Evolution is, of course, a biological fact, but for the new atheists it thas become a powerful quasireligious myth by which atheists such as Dawkins confer meaning on the world'. It has become 'a powerful folk-tale about human origins'. (Beattie 2007: 12, quoting Mary Midgley.)

\section{Religious women - atheist men}

Statistics conducted in countries all over the world, for as long as statistics on religion have been collected, confirm that women are more religious than men. This concerns every dimension of religion. Women participate in religious ceremonies more often than men; women pray more often than men; they more likely than men believe in God, a Spirit, or Life Force; they hold matters of faith and religion more important than men do. Women are more committed than men to their religious communities and are less willing to resign from them. Although older women are more religious than young ones, women of all ages are more religious than coeval men are. Women are members of both traditional religious communities and new religious movements more often than men. Young, urban men are the least religious of all groups. This is equally true also in such religious traditions that seem to be hostile to women, such as fundamentalist traditions (see, for example, Berger et al. 2008: 109; Davie 2000; Freese 2004; Furseth 2009; Miller \& Hoffmann 1995; Niemelä 2003, 2010).

Non-religiosity and secularity are gendered too. In Finland, according to different data sets, ${ }^{4}$ approximately 3-5 per cent of Finns identify themselves as convinced atheists. According to the World Values 2005 survey, 50 per cent of Finnish men consider

4 World Values Surveys 1981-2005; The Church Monitor 2007; International Social Survey Programme (ISSP 2008).

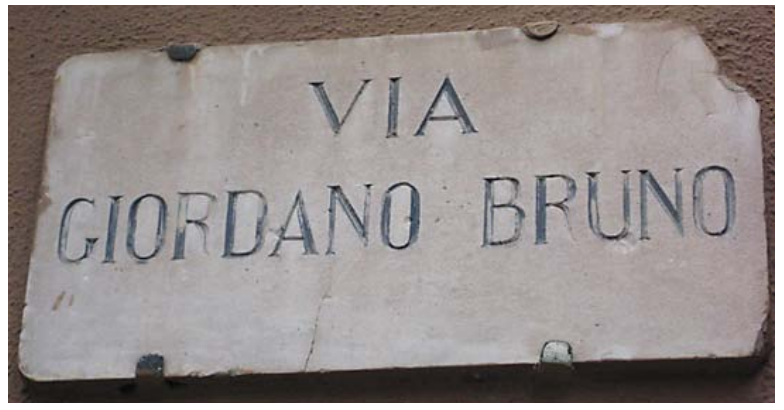

Via Giordano Bruno in Messina, Sicily. Giordano Bruno (1548-1600) was burnt at stake for his heretic views. Thousands of women who met the same fate have remained without statues or streets named after them. Photo by Tomas Mansikka.

themselves as religious, 44 per cent non-religious and 4 per cent as convinced atheists ( $2 \%$ did not know), whereas in the whole population the equivalent percentages are 58 per cent (religious), 36 per cent (nonreligious) and 3 per cent (convinced atheist) (3\% did not know), thus demonstrating that non-religiosity and atheism are more common among men. Altogether 2 per cent of Finnish females consider themselves to be atheists, while 5 per cent of men do the same. The same survey confirms that 23 per cent of Finnish women consider religion to be an important aspect in their lives, whereas only 12 per cent of Finnish men have this opinion. The International Social Survey Programme (ISSP 2008) attests that 20 per cent of Finns believe in God without any doubts; 25 per cent despite their doubts. Among women 25 per cent believe in God without any doubts, but among men only 15 per cent. Approximately 8 per cent of women and 15 per cent men have no belief in God, Spirit, or Life Force. (Monikasvoinen kirkko 2008: 41, 44-5; Borg et al. 2007; Furseth 2009; Ketola et al. 2011.) All the surveys examined above point out that women are more religious than men and that men are more non-religious and atheistic than women. Although the number of religious men is smaller than the number of religious women, there are still more religious than non-religious men. However, it is not just the quantity of religiosity that is gendered, but also the content of religiosity that differs between men and women.

Men have proved to be more resolute than women as to religious beliefs. In other words, both atheists and fundamentalists are more often men than women. A tendency among men is to accept 'the whole package', which means that they are more apt to embrace everything pertaining to their (Christian) belief. Women are more selective; they believe 
in a loving God, but not in Hell, the Devil or the Last Judgment. The world-view of women can even consist of beliefs which contradict each other; a belief in the resurrection of Jesus does not prevent women from believing in reincarnation and astrology as well. According to Kati Niemelä, men are looking for an explicit pronouncement; they do not commit themselves to loose or unclear religiosity (Niemelä 2010).

Although men are more passive as regards participating in religious events, more unwilling to believe in one God and a life after death, they do wish, almost as often as women, to maintain religious practices in moments of life transitions, such as birth, marriage and death. Religious rituals thus also occupy an important place in the lives of men (Niemelä 2003: 189).

\section{Why does religion attract women and atheism men?}

Contemporary studies of religion seem to prove unvaryingly that women tend to be more religious than men. A stronger religiosity is found among women in all European countries as well as in the whole of the Western world. There are several different strands and approaches for explaining this phenomenon. Some

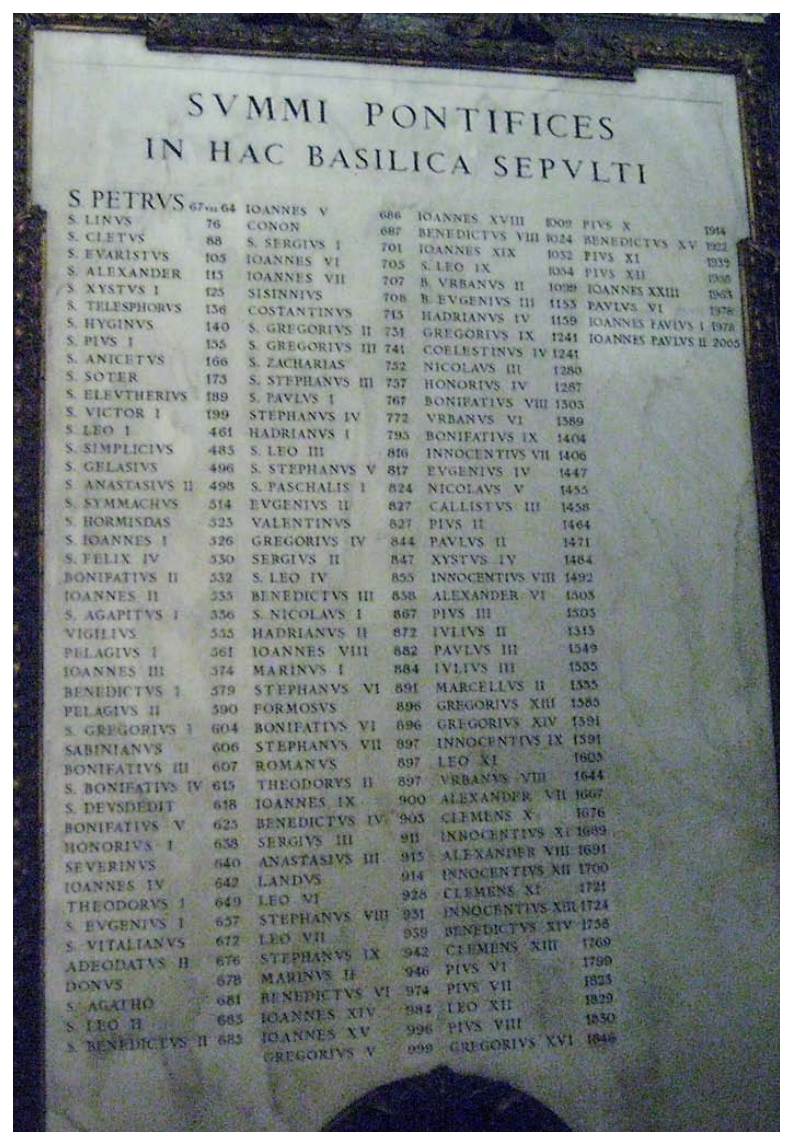

A list of popes, Vatican, Rome, contains no names of women - at least not yet. Photo by Tomas Mansikka. models of explanation have been suggested, but none of them is unanimously acknowledged as established. Can the different modes of socialisation or different kinds of social obligations projected for women and men explain the difference? Or do women and men simply, in some basic and fundamental way - biologically or socially - differ from each other?

One suggested model of explanation is education. Historically women have obtained much less education than men, and more educated women tend to be less religious than their less educated sisters. Education could be seen to shield individuals from adopting supernatural beliefs, thus associating a lack of education with vulnerability. However, when women have taken the opportunity to educate themselves, the disparity is maintained, as educated women in comparison are also more religious than their male equals. Another model of explanation has been socialization. In the same way that women are taught to be more submissive, passive and obedient than men, they are also more religious. Women's traditional roles as caretakers - giving birth and nursing babies, caring for sick and dying persons - puts them into a more immediate relationship with the ultimate questions of life and death. At least historically, women's social life has been more restricted than men's. This in turn could be seen to engender more conservative and traditional value systems for women than for men. But most often the stronger religiosity of women is connected to the fact that women are more involved in bringing their children up, maintaining the chain of memory and traditions. In addition, women spend much more time at home, having more time to practice religion and consider religious questions (this explanation must have come from a man who has never spent time at home with all the responsibilities it involves). But statistics also show that women working outside the home are as religious as women who work at home. (Berger et al. 2008: 109-12; Davie 2000; Freese 2004; Miller \& Hoffman 1995; Niemelä 2003, 2010; Woodhead 2007.)

Recent studies indicate that gender differences in religiousness might be caused by biological and psychological factors - an explanation that is based on nature not on nurture (Berger et al. 2008: 111). What is it in sex difference that exposes or shields one from religion? What models could explain the differences of religiosity not only between the sexes, but also within each sex? Different studies show a significant relationship between gender orientation and being religious; masculinity and femininity are identified as important determinants of both women's and men's 
religiosity. Men with a feminine orientation share a greater religious involvement than men with a masculine orientation. The results also indicate that feminine women are more religious than women with a masculine orientation. (Miller \& Hoffman 1995, Thompson \& Rennes 2002, Freese 2004.)

The standards of masculinity within Western culture encourage men to seek adventure, danger, and to take risks. In some studies the gender difference in religiousness is explained by risk preferences: men are more likely to commit crimes, they behave violently, when driving they are often convicted of speeding, they hunt large and dangerous animals, and so on. According to these researches irreligiousness and the rejection of religious beliefs are part of a typically masculine risk-taking behaviour (Miller \& Hoffman 1995, Thompson \& Rennes 2002, Niemelä 2010). These results can be interpreted in many ways. They might lead us to assume that atheists tend to be masculine risk-takers. We should however also remember - as Abby Day remarked during a conversation - all of the risks that women are exposed to: giving birth to children, enduring violent marriages, walking out in a mini skirt at midnight in parks and so on. Aren't they forms of risk-taking, too?

\section{A conflict between religion and women? Feminism, religion and atheism}

Although women tend to be religious, there are, of course, non-religious women and even non-religious mothers. Especially women with feminist attitudes tend to be non-religious. Second wave feminism, in particular, views religion as highly problematic: as patriarchal, misogynic and oppressive. Many feminist women have found it hard to remain within their religious traditions (see, for example, Furseth 2009: 210). Feminist texts and (second wave) feminist research join with the discourses of the new atheists in articulating, quite correctly, that religious traditions have in many ways legitimated the oppression and discrimination of women. Within the world religions both actors and leaders have been, and still are, men. Also religious beliefs and doctrines have been historically transmitted by men to men, as the contact and communication with the supernatural has been the privilege of men. The founders of the great world religions have also been male, as well as most of those who have instituted religious communities. And not only have the sacred texts been written by men, but nearly all of the great figures, saints, martyrs, teachers and leaders of religious traditions - at least those we know by name - have been men. Women have also been excluded from various religious rituals, and there has been an extensive debate within religious traditions in the West as to whether women possess an immortal soul. The possibility for women to reach salvation has mostly been spelled out in terms of suppression and renunciation: to reject sexuality, motherhood and marriage, and to withdraw to a monastery and wholly give up one's life to God. Although women have, in some religious traditions - for instance revival movements - had an important role as preachers or prophets in the movements' early stages, they have later been removed from leading positions when the movement has become more organised (see, for example, King 1987; Nenola 1988, 1999; Woodhead 2009; Young 1987).

From the points of view illustrated above - bearing in mind of course that it is not the whole picture, but a picture second wave feminism and new atheism usually gives - it appears as a miracle that women have not left their churches and religions en masse and converted to atheism. The situation is quite to the contrary, as we have seen: even feminist women tend to be religious. Some of them have left their churches, some have tried to reformulate and reinterpret their tradition in woman-friendly directions. Some of the religious feminists have founded totally new woman -centred forms of religion and spirituality. Thus, feminists can be atheists, but they are not necessarily so. As a matter of fact, many feminists who identify themselves as atheists have experienced the culture of discussion within atheist circles to be quite masculine and misogynic; they perceive atheism as a project belonging to white western men (Beattie 2007, Woodhead 2007, Furseth 2009).

What is significant here is that the arguments put forward against religion are quite similar, both of the new atheists and the (second wave) feminists. They resemble each other in many ways. Unfortunately, very little research has been done on the relationship between atheism and feminism. There are, however, exceptions, such as work by Christine Overall (2006) and Inger Furseth (2009). Furseth, leaning on both quantitative and qualitative data sets, illustrates gendered structures in worldviews. She shows that both feminist identities and masculine rationality lead away from religion - but not necessarily from spirituality. An article by Christine Overall examines arguments by feminists who are critical of religion such as those discussed in the previous paragraph. When taking the critical arguments at face value, Overall considers whether these feminists should 
be atheists as well. However, as Overall and several other researchers point out, religious traditions do not exist outside of, or apart from, social and cultural phenomena, but reflect them - this gives one explanation for androcentrism in the religious traditions of the world. From a historical perspective female activities and influence have been situated outside the institutions of society, for instance outside scientific and theological educational institutions. Because of this, women have not been able to participate in the construction and formulation of processes within social institutions, including religious traditions and rituals. (Overall 2006: 235; Nenola 1988, 1999; Young 1987.)

Both (second wave) feminists and new atheists see the practices associated with religious and cultural traditions as being harmful to women. The norms which restrict women's lives concern first and foremost sexuality: birth control, abortion or divorce may be prohibited; any forms of sexuality beyond what is included in a heterosexual marriage may be seen as illegitimate; women's importance lies most often in being a wife or a mother, while the value of infant girls, as well as older women or widows, are mostly minimal (Overall 2006: 235; Nenola 1988, 1999).

For these and many other reasons feminism and religion are often regarded as opposites. Women with feminist orientations are alienated from religious traditions, and feminist research has not been able to positively evaluate religion or religious traditions. Religious women are seen as either ignorant or gripped by an erroneous perception. Both (second wave) feminist sociological studies of religion and the writings of the new atheists approach religion and women's religiosity in a black-and-white way: either a great deal of space is given to religion, or it is totally bypassed. Especially when considering women from remote or unfamiliar cultures, there is a tendency to dwell on religious points of view alone. Religion becomes the only lens through which women are scrutinised, as if there were no other dimensions to their lives. A well-known example is that of the veiled Muslim woman, who has become a metaphor for submission and ignorance - the sexual and racial 'other'. The idea of an educated, independent, professional feminist Muslim woman doesn't fit into the frame. (Vuola 2010a: 171-2, 201ob: 137; Beattie 2007: 66; Berger et al. 2008: 113.)

The new atheist and feminist scholars who bypass the multidimensionality of religious traditions share a common attitude; an inability to discern between different levels and dimensions of religion and re- ligiosity. They focus merely on levels of institutions, interpretations of the elite, and on holy scriptures and dogmas. As a result, the lived, everyday religion and interpretations and experiences of ordinary people are left out. The monotheist religions of the Near East appear, for sure, to be very patriarchal, if one is solely concentrating on official interpretations (Vuola 2010a: 173). Both traditionally feminist and new atheist critics of religion tend to focus on theological questions, in conjunction with interpretations of religion from biological perspectives. This means that they often get caught up in details, as for example issue of the hymen - was Mary a virgin before, during and after giving birth to Jesus? - and do not regard as meaningful or relevant the actual beliefs held by ordinary religious persons, or the appropriate hermeneutics usually applied to sacred texts. (Vuola 201ob: 81.) Elina Vuola gives examples of interpretations by Latin American women of the myth of the Virgin Mary, which differ in many ways from the official interpretations of the Catholic Church - which interpretations many of the women were not even aware of. When focusing on the Mariology of the Catholic Church, the Virgin Mary is seen as an origin and a symbol of the subordination of women - the same effect is happening with the scarf worn by Muslim women. The symbol can, in both of these cases, be 'the vehicle of the subordination, but it cannot be it without considering the other preconditions, women's self-understanding and cultural identity, which is more than religious identity?. (Vuola 2010a: 179.)

Elina Vuola (2010a: 174) points out an important duty of the scholar of religion: to correct the most stereotypical perceptions on religion and gender in other disciplines and in public discussions - and not contributing to their further dissemination. She also reminds us that the cultural clash is not occuring - at least not in the domain of sexual ethics - between different religious traditions, but within them. Christianity, Judaism and Islam agree in practice on sexual ethics and family legislation, at least concerning questions of homosexuality and abortion. It is the polarisation within religions which is much more important. (Vuola 2010a: 175.) Religious communities usually become divided into opposing camps conservatives and liberals - with varying and incompatible attitudes towards modernisation, pluralism, lifestyle, gender and sexuality (Ketola 2006: 309-10). It is the conservative factions of devotees that become the target of the new atheist (and feminist) critics, while liberal religiosity is seen as a platform 
for potential conservatism (and fundamentalism). Vuola recommends, for dealing with different forms of religiosity, taking a position which simultaneously critical and which seeks to understand. A scholar of religion must distinguish between conceptual and functional levels of religious traditions; to discern the difference between religion in terms of institutions, doctrines, or religious elites, and the lived religion of ordinary people. (Vuola 2010a: 181.) Only then may one understand in what ways women have found the space to develop their talents within (the patriarchal) religious traditions, as well as in what ways the religions have become resources for women, and have given support, meaning and substance to women in their everyday lives (Berger et al. 2008: 112; Nenola 1988, 1999).

\section{Whose voices are heard?}

Altough women do tend to be more religious than men, there is a growing number of women who are distancing themselves from religion, or women for whom religion is not regarded as important in their lives. Still, very few of these women identify themselves as convinced atheists, even when they share a common attitude with atheists; namely that religions are harmful to societies, and religious beliefs are false from a scientific perspective. The forms of non-religiousness amongst these women varies from indifference on religious issues to extreme forms of atheism.

In Finland, atheism has not become popular on a large scale; a more likely and common standpoint is to be religiously indifferent, even when one is a member of the Finnish Lutheran Church. Those who leave the Church are seldom convinced atheists, but people who feel themselves to have been offended or disappointed by Church employees, or by some of the attitudes supported by the Church. They may also simply be alienated from the teachings of the Church, or the doctrines of Christianity, and do not regard them as important or meaningful for their lives (see Niemelä 2006). Finns do not reflect overly much on religious questions in their everyday lives, or weigh up the scientific evidence pertaining to certain religious beliefs. Teemu Taira has followed discussions on atheism, and by atheists, in the leading Finnish newspaper Helsingin Sanomat, and maintains that although contemporary Finns are not passionate defenders of religion, this doesn't make them active supporters of atheism. The most visible and noisy Finnish atheists focus their criticism on the Finnish Lutheran Church and its visibility and status within
Finnish society. There have also been lively debates on religious education in public schools and its secular equivalent, the study of the philosophy of life. Of all the atheist interviewees only two were women. (Taira 2008: 66, 68-76.) The same tendency was explicit in the lively debate on science versus religion in the leading Swedish-speaking newspaper Hufvudstadsbladet during the spring of 2011. The male counterparts in the discussion - where science and the theory of evolution was pitted against theism and the Church - did more or less disregard each other's views, with no serious attempts at understanding each another.

What are still mostly invisible in the public discussion are the varieties and forms of everyday nonreligiousness, the lived non-religiousness. It would be important to examine, for instance, the ways in which non-religious mothers and families raise their children in everyday life and in times of crisis. How they organise transition rites or annual festivals, the contents and forms of which are mostly based on Christianity. How children of non-religious families experience the presence of (Christian) religion (festivals, prayers, hymns) in kindergarten or at school. What do the worldviews of non-religious people consist of? Or what forms or dimensions of spirituality are closest to the views of secular people?

Dr and Docent Tiina Mahlamäki is Lecturer in Comparative Religion at the University of Turku, Finland. She is member of the executive board of the Finnish Society for the Study of Religion, and the co-editor-in-chief of Temenos: Nordic Journal of Comparative Religion. Her main research themes are: literature and religion, gender and religion (both religiosity and nonreligiosity) and civil religion. She has recently written on Emanuel Swedenborg's influence on Finnish national literature and on the Anthroposophical themes in the works of the Finnish female author Kersti Bergroth. Email: tituma(at)utu.fi.

\section{Bibliography}

Beattie, Tina 2007. The New Atheists: The Twilight of Reason \& The War on Religion. New York: Orbis.

Berger, Peter, Grace Davie \& Effie Fokas 2008. Religious America, Secular Europe? A Theme and Variations. Aldershot: Ashgate.

Borg, Sami, Kimmo Ketola, Kimmo Kääriäinen, Kati Niemelä \& Pertti Suhonen 2007. Uskonto, arvot ja 
instituutiot. Suomalaiset World Values -tutkimuksissa 1981-2005. [Religion, Values and Institutions: The Finns in the World Values Surveys 1981-2005.] Tampere: Yhteiskuntatieteellinen tietoarkisto.

Brooke, John Hedley 1991. Science and Religion: Some Historical Perspectives. Cambridge: Cambridge University Press.

Davie, Grace 2000. Religion in the Modern Europe: A Memory Mutates. Oxford: Oxford University Press.

Davie, Grace \& Linda Woodhead 2009. 'Secularization and secularism'. In: Linda Woodhead, Hiroko Kawanami \& Christopher Partridge (eds), Religions in the Modern World: Traditions and Transformations. 523-34. 2nd ed. London: Routledge.

Ferngren, Gary B. (ed.) 2002. Science \& Religion: A Historical Introduction. Baltimore \& London: The Johns Hopkins University Press.

Freese, Jeremy 2004. 'Risk Preferences and Gender Differences in Religiousness: Evidence from the World Values Survey.' Review of Religious Research 46 (1): 88-91.

Furseth, Inger 2009. 'Atheism, Secularity, and Gender.' In: Phil Zuckerman (ed.), Atheism and Secularity. Volume 1: Issues, Concepts, and Definitions. 209-27. Santa Barbara: Praeger.

Hyman, Gavin 2010. A Short History of Atheism. London: I. B.Tauris.

Ketola, Kimmo 2006. 'Kaupunkien uusi henkisyys' [The New Urban Spirituality]. In: Teija Mikkola, Kati Niemelä \& Juha Petterson (eds), Urbaani usko. Nuoret aikuiset, usko ja kirkko. [Urban Faith: Young Adults, Faith and the Church.] 305-16. Tampere: Kirkon tutkimuskeskus.

Ketola, Kimmo, Kati Niemelä, Harri Palmu \& Hanna Salomäki 2011. Uskonto suomalaisten elämässä. Uskonnollinen kasvatus, moraali, onnellisuus ja suvaitsevaisuus kansainvälisessä vertailussa. [Religion in the Life of the Finns: Religious Upbringing, Morality, Happiness and Tolerance in International Perspective.] Tampere: Yhteiskuntatieteellinen tietoarkisto.

King, Ursula (ed.) 1987. Women in the World's Religions: Past and Present. New York: Paragon House.

Miller, Alan \& John P. Hoffmann 1995. 'Risk and Religion: An Explanation of Gender Differences in Religiosity. Journal for the Scientific Study of Religion 34 (1): $63-75$.

Monikasvoinen kirkko. Suomen evankelis-luterilainen kirkko vuosina 2004-2007. [Multifaceted Church: The Finnish Lutheran Church in 2004-2007.] 2008. Kirkon tutkimuskeskuksen julkaisuja 103. Tampere: Kirkon tutkimuskeskus.

Nenola, Aili 1988. 'Seinään isketty naula. Uskonto naiseuden ja naisen roolien määrittelijänä.' [Religion defining the femininity and the roles of women.] Naistutkimus 1: 19-28.

-1999. 'Naisen ja miehen uskonto' [Religion of Woman and Man]. In: Katja Hyry \& Juha Pentikäinen (eds), Uskonnot maailmassa [Religions in the World]. 479-9o. Helsinki: WSOY.
Niemelä, Kati 2003. 'Uskonnollisuus eri väestöryhmissä' [Religiosity in different population groups]. In: Kimmo Kääriäinen, Kati Niemelä \& Kimmo Ketola, Moderni kirkkokansa. Suomalaisten uskonnollisuus uudella vuosituhannella. [Modern Church Folk: Religiosity of the Finns in the New Century.] 187-220. Tampere: Kirkon tutkimuskeskus.

-2006. Vieraantunut vai pettynyt? Kirkosta eroamisen syyt Suomen evankelis-luterilaisessa kirkossa. [Alienated or disappointed? The reasons for resigning from the Evangelical-Lutheran Church of Finland.] Tampere: Kirkon tutkimuskeskus.

-2010. 'Miesten uskonnollisuus ja henkisyys' [The Spirituality and Religiosity of Men]. Tasa-arvo 1/2010.

Overall, Christine 2006. 'Feminism and Atheism.' In: Michael Martin (ed.), The Cambridge Companion to Atheism. 233-49. Cambridge: Cambridge University Press.

Pyysiäinen, Ilkka 2011. 'Johtaako uskonnon ja tieteen törmäys tyrmäykseen?' [Does the crash between religion and science lead into knockout?] In: Jussi K. Niemelä (ed.), Mitä uusateismi tarkoittaa? [What Does New Atheism Mean?] 54-69. Turku: Savukeidas. Taira, Teemu 2003. 'Usko, uskonto, uskontokritiikki' [Faith, religion and criticism of religion]. Tieteess $\ddot{a}$ tapahtuu 8: 60-3.

-2008. 'Ateismi kieltäytymisen historiana' [Atheism as a history of refusal.] In: Mari K. Niemi (ed.), Kiitos ei! Kieltäytymisen kulttuurihistoriaa. [No Thanks! The Cultural History of Refusal.] 50-77. Helsinki: Ajatuskirjat.

Thompson, Edward H. Jr. \& Kathyrn R. Remmes 2002. 'Does Masculinity Thwart being Religious? An Examination of Older Men's Religiousness.' Journal for the Scientific Study of Religion 41 (3): 521-32.

Visala, Aku 2010. 'Uusateismin haaste' [The challenge of New Atheism]. In: Maarit Hytönen (ed.), Minä uskon? Jumala-usko 2010-luvulla [I Believe? Believing in God in the 2010s.] 29-46. Tampere: Kirkon tutkimuskeskus.

Vuola, Elina 2010a. 'Feministinen uskonnontutkimus' [The feminist study of religion]. In: Tuija Saresma, Leena-Maija Rossi \& Tuula Juvonen (eds), Käsikirja sukupuoleen [Handbook of Gender]. 170-82. Tampere: Vastapaino.

-2010b. Jumalainen nainen. Neitsyt Mariaa etsimässä. [The Divine Woman: Searching for the Virgin Mary.] Helsinki: Otava.

Woodhead, Linda 2007. 'Gender Differences in Religious Practice and Significance.' In: The Sage Handbook of the Sociology of Religion. 550-70. London: Sage. http://eprints.lancs.ac.uk/793/.

-2009. 'Religion and gender.' In: Linda Woodhead, Hiroko Kawanami \& Christopher Partridge (eds), Religions in the Modern World: Traditions and Transformations. 471-88. London: Routledge.

Young, Catherine 1987. 'Introduction'. In: Arvind Sharma (ed.), Women in World Religions. 10-36. Albany: State University of New York Press. 